\title{
GAMBARAN UPAYA DALAM MEMENUHI KEBUTUHAN TIDUR LANSIA DI PANTI SOSIAL TRESNA WERDHA JARA MARA PATI SINGARAJA
}

\author{
Wijayantha, I Putu Arya ${ }^{1}$; Putra, I Gede Yudiana ${ }^{2 *}$; Rasdini, I Gusti Ayu Ari $^{3}$ \\ Sukanti, I Nengah ${ }^{4}$ \\ ${ }^{1,2,4}$ Akademi Keperawatan Kesdam IX/Udayana \\ ${ }^{3}$ Politeknik Kesehatan Denpasar \\ *Korespondensi: theyjezzjazz@yahooo.id
}

\begin{abstract}
Backgroud: Elderly is a most vulnerable to disease. Most elderly people have psychological disturbances due to the tension because it is not able to adapt to the changes experienced. One of the impacts caused by stress or emotional tension is sleep disturbance. To solve the emotional stress is needed relax condition or action that is pharmacologic and non-pharmacologic assisting elderly to fall a sleep. This study aims to determine the efforts made in meeting the needs of the elderly sleep. Methods: The method used in this study is structured interviews. Of 60 samples obtained through purposive sampling technique. The data was collected through questionnaires and interviews with the guidelines made by direct questioning of respondents and researchers have known for sure about what information will be obtained.Results: The results obtained after research are most forms of sleep problem in insomnia elderly $(53,33 \%)$, most of the pharmacologic efforts in meeting the needs of the elderly sleep is taking the herbs $(48,33 \%)$ and most of the effort in meeting the needs sleep non-pharmacologic elderly is a lifestyle change (48.33\%). Conslusion: Based on these results, it is recommended to nurses or nursing staff to be able to make this research as a basis for thinking in meeting the needs of elderly and bed use and the pharmacological action suit nonpharmacologic sleep problems experienced by elderly.
\end{abstract}

Keywords: Requirement of Sleep; Efforts; Elderly;

\begin{abstract}
ABSTRAK
Latar Belakang: Lansia merupakan suatu individu yang sangat rentan terkena penyakit. Sebagian besar lansia mengalami gangguan psikologis akibat ketegangan karena tidak mampu beradaptasi dengan perubahan yang dialami. Salah satu dampak yang ditimbulkan akibat stress atau ketegangan emosional adalah gangguan tidur. Untuk mengatasi ketegangan emosional dibutuhkan suatu terapi atau tindakan yaitu farmakologi dan nonfarmakologi yang membantu lansia untuk tertidur. Penelitian ini bertujuan untuk mengetahui upaya yang dilakukan dalam memenuhi kebutuhan tidur lansia. Metode: Metode yang digunakan dalam penelitian ini adalah kegiatan wawancara terstruktur. Sampel berjumlah 60 orang yang didapatkan melalui teknik purposive sampling. Pengumpulan data dilakukan
\end{abstract}


melalui wawancara dengan pedoman kuesioner dan dilakukan dengan tanya jawab langsung pada responden dan peneliti telah mengetahui dengan pasti tentang informasi apa yang akan diperoleh. Hasil: Hasil yang didapatkan setelah melakukan penelitian adalah sebagian besar bentuk masalah tidur lansia adalah insomnia $(53,33 \%)$, sebagian besar upaya farmakologi dalam memenuhi kebutuhan tidur lansia adalah mengkonsumsi obat herbal $(48,33 \%)$ dan sebagian besar upaya nonfarmakologi dalam memenuhi kebutuhan tidur lansia adalah merubah gaya hidup (48,33\%). Simpulan: Berdasarkan hasil penelitian tersebut, disarankan kepada perawat ataupun petugas panti untuk dapat menjadikan penelitian ini sebagai dasar pemikiran dalam memenuhi kebutuhan tidur lansia dan menggunakan tindakan farmakologi maupun nonfarmakologi sesuai masalah tidur yang dialami lansia.

Kata Kunci: Kebutuhan Tidur; Upaya; Lansia.

\section{PENDAHULUAN}

Menurut data UNFPA (2010), jumlah penduduk lansia yang berusia 60 tahun atau lebih, telah mencapai 737 juta jiwa. Dari jumlah tersebut sekitar dua pertiga tinggal di negara-negara berkembang, termasuk di Indonesia. Dimana diproyeksikan bahwa pada tahun 2050 jumlah penduduk diatas usia 60 tahun itu akan mencapai sekitar 2 milyar jiwa. Semakin banyaknya jumlah lansia ternyata juga mempunyai beberapa dampak yang kurang menggembirakan. Banyak permasalahan lansia yang muncul di bidang kesehatan. Misalnya penyakit dan kelainan yang prevalensinya menjadi meningkat disebabkan karena organ-organ tubuh yang mengalami proses penuaan akan mengalami penurunan fungsi sehingga menjadi rentan terhadap timbulnya penyakit yang bersifat multiorgan.

Tidak hanya perubahan kondisi fisik (sistem organ), perubahan kondisi mental dan psikososial juga dapat terjadi pada lanjut usia. Pemenuhan kebutuhan tidur merupakan salah satu permasalahan yang banyak dialami para lansia. Secara fisiologis, kebutuhan tidur dipengaruhi oleh zat-zat neurotransmitter yaitu serotonin dan melatonin yang disekresikan oleh kelenjar pineal. Serotonin dan melatonin dikeluarkan dalam darah dan akan mempengaruhi terjadinya relaksasi sehingga membuat orang menjadi mengantuk dan tidur (Sudoyo, 2006). Konsentrasi serotonin dan melatonin berkurang sesuai dengan bertambahnya usia sehingga lansia mengalami gangguan pemenuhan kebutuhan tidur. Hal tersebut mengakibatkan lansia akan beresiko untuk jatuh, penurunan stamina, mengurangi produktivitas dan yang terpenting adalah mengakibatkan penyakit-penyakit 
degeneratif yang sudah diderita mengalami perburukan serta menjadi tidak terkontrol.

Pengobatan secara farmakologi atau yang familier disebut farmakoterapi lebih terkosentrasi pada menggunakan obat-obatan seperti benzodiazepine, antikonvulsan, antidepressant, antipsikotik serta hipnotik lainnya. Sedangkan pengobatan secara non farmakologi dapat dilakukan dengan farmakoterapi seperti terapi kontrol stimulus, terapi kognitif, terapi relaksasi, terapi pembatasan tidur serta sugesti hygieni tidur.

Berdasarkan penelitian The Gallup Organization didapatkan data bahwa lebih dari $50 \%$ penduduk lansia dunia pernah mengalami gangguan pemenuhan kebutuhan tidur (Sudoyo, 2006). Hal serupa juga terjadi di Indonesia dimana prevalensi lansia yang mengalami gangguan pemenuhan kebutuhan tidur adalah sebesar $67 \%$. Gangguan tersebut mempengaruhi 50\% orang yang berusia 65 tahun ke atas yang tinggal di rumah dan $66 \%$ yang tinggal di fasilitas perawatan jangka panjang (Maryam, 2008).

Data serupa juga di dapatkan pada Panti Sosial Tresna Werdha (PSTW) Jara Mara Pati Singaraja. Berdasarkan hasil studi pendahuluan yang dilakukan penulis pada bulan Desember 2011 diperoleh data dari 69 orang lansia yang menghuni panti, 50 orang mengalami gangguan baik dalam pola maupun jumlah jam tidurnya. Keluhan yang diungkapkan berbeda-beda pada setiap lansia. Ada yang mengatakan sulit untuk memulai tidur sebanyak 30 orang (60\%), ada yang mengatakan sering terjaga pada saat malam hari sebanyak 10 orang (20\%) dan susah untuk melanjutkan tidurnya sebanyak 10 orang (20\%). Keluhan lain yang diungkapkan yaitu ada yang memiliki jam tidur kurang dari 5-6 jam perhari (70\%) dan ada yang memiliki jam tidur lebih dari 7 jam perharinya (30\%). Berbagai tindakan telah dilakukan dalam menangani gangguan pemenuhan kebutuhan tidur baik oleh petugas panti maupun oleh lansia itu sendiri. Seperti contoh berdasarkan wawancara yang dilakukan oleh penulis kepada petugas panti, dikatakan bahwa memang hampir semua lansia mengalami gangguan tidur seperti susah untuk memulai tidur malam, terjaga saat malam hari, dan badannya terasa pegal-pegal setelah bangun tidur. Upaya khusus yang dilakukan petugas panti apabila keluhan tidur dirasakan sangat mengganggu kondisi fisik lansia biasanya dengan 
memberikan obat tidur seperti diazepam. Hasil yang diperoleh dengan pemberian obat tersebut adalah cukup membantu.

Tujuan penelitian ini untuk mengetahui gambaran tentang upaya yang dapat memenuhi kebutuhan tidur lansia di Panti Sosial Tresna Werdha Jara Mara Pati Singaraja.

\section{METODE}

Jenis penelitian yang digunakan adalah deskritif. Pada penelitian ini penulis tidak melakukan intervensi tetapi hanya menggambarkan upaya dalam memenuhi kebutuhan tidur lansia. Penelitian dilaksanakan di Panti Sosial Tresna Werdha Jara Mara Pati Singaraja, yang terletak di Jalan Arjuna, Desa Kaliasem, Kecamatan Banjar, Kabupaten Buleleng, Provinsi Bali yang dilakukan selama tiga bulan dari bulan april sampai juni. Jumlah populasi yang tinggal di Panti Sosial Tresna Werdha Jara Mara Pati Singaraja yang berjumlah 69 orang. Pada penelitian ini teknik sampling yang dipakai adalah Purposive Sampling sehingga jumlah sampel terdapat 60 orang ditetapkan berdasarkan kriteria inklusi dan kriteria eksklusi. Kriteria Inklusi: Lansia yang mampu berkomunikasi dengan baik; Lansia yang bersedia mengikuti penelitian ini dengan menandatangani informed consent; Lansia berusia 60 tahun ke atas. Kriteria Eksklusi: Lansia yang didiagnosa mengalami demensia berat; Lansia yang mengalami penyakit fisik sehingga menyebabkan nyeri berat; Lansia yang mengalami ketergantungan obatobatan tertentu seperti Narkotika dan Antidepresan.

Instrumen yang dipakai pada penelitian ini adalah dengan menggunakan kuesioner yang dibantu dengan menggunakan paduan wawancara Kuesioner yang telah diuji validitasnya pada bulan April di Panti Sosial Tresna Werdha Wana Seraya Denpasar. Kuesioner yang digunakan pada penelitian ini dibuat terstruktur sehingga memungkinkan responden dapat menjawab semua pertanyaan yang diajukan mengenai upaya dalam memenuhi kebutuhan tidur. Teknik analisa data yang digunakan adalah analisis deskriptif. 


\section{HASIL}

Karakteristik Responden Penelitian: Data karakteristik responden, dikumpulkan melalui wawancara dengan responden. Instrumen yang digunakan adalah kuesioner. Karakteristik responden yang telah diteliti kemudian didistribusikan ke dalam tabel distribusi sebagai berikut.

Tabel 1. Distribusi Frekuensi Karakteristik Responden Berdasarkan Jenis Kelamin

\begin{tabular}{ccc}
\hline Jenis Kelamin & Jumlah $(\mathbf{n})$ & Presentase $(\boldsymbol{\%})$ \\
\hline Laki-laki & 16 & 26,67 \\
Perempuan & 44 & 73,33 \\
\hline Total & 60 & 100 \\
\hline
\end{tabular}

Dari tabel 1 diatas dapat dilihat bahwa sebagian besar responden merupakan perempuan yaitu sebanyak 44 responden $(73,33 \%)$.

Tabel 2. Distribusi Frekuensi Karakteristik Responden Berdasarkan Usia

\begin{tabular}{ccc}
\hline Usia (tahun) & Jumlah (n) & Presentase (\%) \\
\hline $60-74$ (lansia dini) & 26 & 43,33 \\
$75-90$ (lansia tua) & 33 & 55,00 \\
$>90$ (lansia sangat tua) & 1 & 1,67 \\
\hline Total & 60 & 100 \\
\hline
\end{tabular}

Dari tabel 2 diatas dapat dilihat bahwa sebagian besar responden merupakan lansia tua (75-90 tahun) yaitu sebanyak 33 responden (55\%).

Tabel 3. Distribusi Frekuensi Bentuk Gangguan Tidur Lansia

\begin{tabular}{ccc}
\hline Bentuk Gangguan Tidur & Jumlah (n) & Prersentase (\%) \\
\hline Insomnia & 32 & 53,33 \\
Parasomnia & 4 & 6,67 \\
Gangguan Jadwal Tidur-Bangun & 24 & 40 \\
\hline Total & 60 & 100 \\
\hline
\end{tabular}

Berdasarkan tabel 3 diatas dapat dilihat bahwa sebagian besar 32 responden $(53,33 \%)$ mengalami gangguan tidur insomnia kemudian diikuti dengan 24 responden (40\%) menggalami gangguan jadwal tidur-bangun. Dan untuk parasomnia hanya 4 responden $(6,67 \%)$ yang mengalami gangguan tidur ini. 
Tabel 4. Disribusi Frekuensi Upaya Farmakologi Dalam Memenuhi Kebutuhan Tidur

\begin{tabular}{ccc}
\hline Upaya Farmakologi & Jumlah (n) & Presentase (\%) \\
\hline Suplemen & 10 & 16,67 \\
Obat Herbal & 29 & 48,33 \\
Obat Penenang & 21 & 35,00 \\
\hline Total & 60 & 100 \\
\hline
\end{tabular}

Berdasarkan tabel 4 menunjukkan bahwa sebagian besar 29 responden $(48,33 \%)$ memilih upaya mengkonsumsi obat herbal dalam memenuhi kebutuhan tidurnya, diikuti dengan 21 responden $(35,00 \%)$ yang menggunakan obat penenang dan 10 responden $(16,67 \%)$ mengkonsumsi suplemen dalam memenuhi kebutuhan tidurnya.

Tabel 5. Disribusi Frekuensi Upaya Nofarmakologi Dalam Memenuhi Kebutuhan Tidur Lansia

\begin{tabular}{ccc}
\hline Upaya Farmakologi & Jumlah (n) & Presentase (\%) \\
\hline Edukasi & 17 & 28,33 \\
Gaya Hidup & 29 & 48,33 \\
Teknik relaksasi & 14 & 23,34 \\
\hline Total & 60 & 100 \\
\hline
\end{tabular}

Berdasarkan tabel 5 menunjukkan bahwa sebagian besar 29 responden $(48,33 \%)$ melakukan upaya nonfarmakologi berupa mengatur gaya hidup dalam memenuhi kebutuhan tidurnya. Kemudian 17 responden $(28,33 \%)$ yang menerima informasi dari petugas panti (edukasi), dan 14 responden $(23,34 \%)$ memilih untuk melakukan teknik relaksasi dalam memenuhi kebutuhan tidurnya.

\section{PEMBAHASAN}

\section{Bentuk Gangguan Tidur Lansia.}

Pada penelitian ini mendapatkan 32 responden $(53,33 \%)$ yang mengalami gangguan tidur insomnia. Insomnia adalah suatu gangguan tidur yang dialami oleh penderita dengan gejala-gejala selalu merasa letih dan lelah sepanjang hari dan secara terus menerus (lebih dari sepuluh hari) mengalami kesulitan untuk tidur atau selalu terbangun di tengah malam dan tidak dapat kembali tidur. Seringkali penderita terbangun lebih cepat dari yang diinginkannya dan tidak dapat kembali tidur. 
Pada gangguan jadwal tidur-bangun yang telah diteliti, didapatkan 24 responden (40\%) yang mengalami gangguan tidur ini. Gangguan jadwal tidurbangun adalah suatu ketidaksejajaran antara perilaku tidur dan bangun. Tipe disorganisasi memperlihatkan pola waktu tidur dan terjaga acak dan tak dapat diramalkan. Keadaan ini dapat terjadi pada orang yang tidur secara sembarangan atau seringkali tidur siang sebentar, khususnya manula atau orang yang lama terbaring di tempat tidur.

Kemudian pada gangguan tidur terakhir yaitu parasomnia didapatkan hanya 4 responden $(6,67 \%)$ yang mengalami gangguan tidur ini. Parasomnia adalah suatu kelainan yang ditandai kejadian perilaku atau psikologis abnormal yang muncul di kala tidur, tahapan tidur tertentu, atau transisi fase tidur-terjaga. Sleepwalking atau tidur berjalan adalah gangguan saat penderitanya berjalan dalam tidur.

\section{Upaya Farmakologi Dalam Memenuhi Kebutuhan Tidur Lansia.}

Pada penelitian ini ditemukan bahwa 29 responden $(48,33 \%)$ memilih upaya mengkonsumsi obat herbal dalam memenuhi kebutuhan tidurnya, diikuti dengan 21 responden $(35,00 \%)$ yang menggunakan obat penenang (parental \& interal) dan 10 responden $(16,67 \%)$ mengkonsumsi suplemen (supplement) dalam memenuhi kebutuhan tidurnya. Ini sesuai dengan teori Ardani (2012), dimana farmakologi sangat umum diberikan untuk pengobatan gangguan tidur sebagai tambahan pengobatan dengan terapi prilaku. Pengaruh dari pemberian farmakoterapi diyakini efektif dalam durasi singkat dan dapat meningkatkan waktu tidur normal dari pasien setelah melakukan farmakoterapi. Hal ini didukung juga oleh teori Williams \& Wilkins (2007), yang menyatakan bahwa farmakologi dalam terapi mengatasi gangguang tidur dapat digolongkan menjadi nonbenzodiazepin (zolpidem), melatonin reseptor agonis (ramelteon), antihistamin, antidepresan, benzodiazepine, herbal, dan suplemen.Suplemen yang mengandung melatonin dapat membantu mengatur ulang jam tubuh dan merupakan terapi tahap pertama untuk mengatasi gangguan tidur saat melakukan perjalanan. Kekurangan melatonin akan mengganggu pola tidur normal, yang menenggelamkan diri di tengah-tengah gangguan-gangguan kesehatan. Melatonin akan kehilangan beberapa potensinya saat tubuh menua. Reseptor-reseptor 
neurotransmitter itu tidak menghasilkan kekuatan yang sesuai dengan dosis melatonin yang mereka terima. Itu sebabnya mengapa sebagian orang menderita gangguan tidur dan gangguan kesehatan yang berhubungan dengan penuaan.

\section{Upaya Nonfarmakologi Dalam Memenuhi Kebutuhan Tidur Lansia.}

Pada penelitian ini 29 responden (48,33\%) melakukan upaya nonfarmakologi berupa merubah gaya hidup dalam memenuhi kebutuhan tidurnya, 17 responden $(28,33 \%)$ yang menerima informasi dari petugas panti (edukasi), dan 14 responden $(23,34 \%)$ memilih untuk melakukan teknik relaksasi dalam memenuhi kebutuhan tidurnya. Upaya Nonfarmakologi sangat membantu dalam mengatasi masalah tidur lansia, karena upaya non-farmakologi merupakan tindakan untuk mengatasi suatu keluhan tanpa menggunakan obat, melainkan menggunakan suatu terapi alternative. Melakukan upaya nonfarmakologi berupa mengatur gaya hidup dalam memenuhi kebutuhan tidurnya. Menghindari kafein, alkohol dan nikotin merupakan salah satu gaya hidup yang mampu mengatasi masalah tidur, mengurangi penerangan saat tidur juga dapat membantu mengatasi masalah tidur. (Yustinus, 2006).

Menurut Mehmet \& Michael (2009) meredupkan lampu beberapa jam sebelum tidur untuk menghindari stimulasi yang disebabkan oleh polusi lampu buatan yang menghampiri melalui TV, komputer dan penerangan dalam rumah dan jadikan suasana remang-remang tersebut sebagai stimulan. Gaya hidup untuk sering berolahraga dapat pula membantu mengatasi masalah tidur yang dialami. Melakukan olahraga, senam atau kegiatan fisik di pagi atau sore hari bisa membantu menghilangkan tekanan mental dan ketegangan otot. Melakukan olahraga aerobic sekurangnya tiga kali seminggu juga meningkatkan rasio kenyamanan tidur. Cukup dengan melakukan peregangan (stretching) yang panjang dan lama sebelum tidur karena akan melepaskan tekanan pada otot dan memudahkan diri untuk tidur. Fokuskan pada asana (pose) yang member efek relaksasi.

\section{SIMPULAN DAN SARAN}

Dari hasil penelitian berdasarkan bentuk gangguan tidur lansia didapatkan 32 responden $(53,33 \%)$ mengalami gangguan tidur insomnia kemudian diikuti 
dengan 24 responden (40\%) menggalami gangguan jadwal tidur-bangun. Dan untuk parasomnia hanya 4 responden $(6,67 \%)$ yang mengalami gangguan tidur ini. Berdasarkan upaya farmakologi dalam memenuhi kebutuhan tidur lansia didapatkan 29 responden $(48,33 \%)$ memilih upaya mengkonsumsi obat herbal dalam memenuhi kebutuhan tidurnya, diikuti dengan 21 responden $(35,00 \%)$ yang menggunakan obat penenang dan 10 responden $(16,67 \%)$ mengkonsumsi suplemen dalam memenuhi kebutuhan tidurnya. Berdasarkan upaya nonfarmakologi dalam memenuhi kebutuhan tidur lansia didapatkan besar 29 responden $(48,33 \%)$ melakukan upaya nonfarmakologi berupa mengatur gaya hidup dalam memenuhi kebutuhan tidurnya. Kemudian 17 responden $(28,33 \%)$ yang menerima informasi dari petugas panti (edukasi), dan 14 responden $(23,34 \%)$ memilih untuk melakukan teknik relaksasi dalam memenuhi kebutuhan tidurnya.

Saran dari penelitian ini adalah Kepada petugas kesehatan khususnya petugas panti disarankan untuk upaya farmakologi dan nonfarmakologi yang diberikan dalam memenuhi kebutuhan tidur lansia tidak hanya mendominasikan satu upaya saja tetapi juga menyeimbangkan dengan upaya lain; Kepada para lansia khususnya lansia di Panti Sosial Tresna Werdha Jara Mara Pati Singaraja, disarankan untuk lebih mendominasi upaya-upaya nonfarmakologi dalam memenuhi kebutuhan tidurnya dikarenakan upaya ini dapat meminimalkan efek samping dari terapi farmakologi; Kepada peneliti selanjutnya disarankan untuk mengembangkan penelitian ini dengan menggunakan lebih dari satu variable dan sampel lebih banyak sehingga didapatkan hasil yang lebih representatif.

\section{UCAPAN TERIMAKASIH}

Puji Syukur penulis panjatkan kehadirat Ida Sang Hyang Widhi Wasa (Tuhan Yang Maha Esa) karena atas berkat dan rahmat-Nya penulis dapat menyelesaikan laporan penelitian ini tepat pada waktunya. Pada kesempatan ini penulis mengucapkan terima kasih kepada: Kepala dan Staff Panti Sosial Tresna Werdha Jara Mara Pati Singaraja atas ijin dan bantuan yang diberikan untuk bisa melakukan penelitian ini; Semua pihak yang tidak bisa kami sebutkan satu per 
satu yang telah membantu kami guna kelancaran dari pelaksanaan kuliah lapangan dan penulisan laporan ini.

\section{DAFTAR PUSTAKA}

Lanywati, E, (2001). Insomnia, Gangguan Sulit Tidur, Edisi I: Jakarta : Kanisius.

Maryam, Siti dkk. (2008). Mengenal Usia Lanjut dan Perawatannya. Edisi Pertama, Jakarta: Salemba Medika.

Sudoyo, A. W. (2006). Buku Ajar Ilmu Penyakit Dalam. Edisi IV. Jilid III. Jakarta: FKUI.

UNFPA. (2010). State Of World Population 2010, (online), (www.unfpa.org, diakses 18 Februari 2011).

Yustinus. (2006). Kesehatan Mental 3. Edisi 1. Yogyakarta: Kanisius. 